\title{
NAPELEMCELLA LABORATÓRIUMI VIZSGÁLATA
}

\author{
Bodnár István \\ egyetemi adjunktus, Miskolci Egyetem, Fizikai és Elektrotechnikai Intézet, \\ Elektrotechnikai és Elektronikai Intézeti Tanszék \\ 3515 Miskolc, Miskolc-Egyetemváros, e-mail: vegybod@uni-miskolc.hu
}

\begin{abstract}
Absztrakt
A tanulmány egy napelemcella laboratóriumi körülmények közötti mérést mutatja be az MSZ EN 60904-9:2008 szabványnak megfelelö Napszimulátor alkalmazásának segitségével. A mérések 600; 800 és $1.000 \mathrm{~W} / \mathrm{m}^{2}$ megvilágítási intenzitásnál négy különbözö cellahömérséklet mellett történtek. A cella hömérséklete hütés nélkül $1.000 \mathrm{~W} / \mathrm{m}^{2}$-nél elérte a $78^{\circ} \mathrm{C}$ hömérsékletet. Erös hütésnél ez az érték csak $47^{\circ} \mathrm{C}$. Hütés nélkül a napelemcella hömérséklete $31^{\circ} \mathrm{C}$ melegedést szenvedett el, a hütött esethez képest, amely következtében 23\%-kal kisebb teljesitményt szolgáltatott. A mérések során az U-I, az U$P$ és az R-P görbék kerültek felvázolásra.
\end{abstract}

Kulcsszavak: Napszimulátor, napelemcella, hömérsékletfüggés, napelem karakterisztika

\begin{abstract}
This paper presents the laboratory measurements of a solar cell with the MSZ EN 60904-9:2008 standard Sun simulator. The measurements were made 600; 800 and 1,000 W/m ${ }^{2}$ intensity of light by four different cell's temperature. The cell's temperature without cooling is $78{ }^{\circ} \mathrm{C}$ by $1,000 \mathrm{~W} / \mathrm{m}^{2}$ intensity of light. The cell's temperature with cooling is $47{ }^{\circ} \mathrm{C}$. The temperature of non-cooled cell $31{ }^{\circ} \mathrm{C}$ more than that cooled cell, as a result of this the power of the solar cell was decreased by 2\%. During the measurements the U-I, U-P and R-P curves were plotted.
\end{abstract}

Keywords: Sun simulator, solar cell, temperature dependence, cell characteristics

\section{Bevezetés}

A napelemek vizsgálata egyre fontosabbá vált napjainkban, egyrészt mert a napelemek üzemi hatásfokát számos környezeti tényező befolyásolja, másrészt pedig mert azok a tényezők egyben visszahatást gyakorolnak a közcélú hálózatra. Ahhoz, hogy minél optimálisabban tudjunk üzemeltetni egy napelemes rendszert (hatásfokmaximum, hosszú élettartam, minimális hálózati visszahatás) minél pontosabban kell ismerni a napelemek és az abból felépített rendszerek müködését. A megismerés folyamata a kísérletezgetés, amely nem csak a mérések elvégzését, hanem szimulációk készítését is egyaránt jelenti. Jelen tanulmányban a mérési úton történő viselkedés-elemzés kerül bemutatásra. Mivel az összehasonlíthatóság és a megismételhetőség nélkülözhetetlen az ilyen jellegü méréseknél, ezért a mérési sorozatot egy erre a célra kifejlesztett Napfényszimulátorral végeztem. A napelemcellát sztenderd és nem sztenderd mérési körülmények mellett egyaránt vizsgáltam. A sztenderd mérési körülmények $1.000 \mathrm{~W} / \mathrm{m}^{2}$ intenzitást írnak elő, amit a Napszimulátor tud teljesíteni [1, 2].

A napelemek névleges villamos paraméterei a sztenderd mérési körülmények között történő mérésekkel határozható meg. Mivel a napelemek a müködési idejük legnagyobb részében nem sztenderd 
mérési körülmények között üzemelnek, ezért más megvilágítási intenzitás és hőmérséklet alkalmazásánál is végeztem vizsgálatokat. Ezen vizsgálati eredmények összességében adnak információkat a napelemek valós müködéséről és a várható energiatermelésröl, hatásfokról és nem utolsó sorban az élettartamról [1,2].

\section{A mérések során használt Napfényszimulátor}

A laboratóriumi vizsgálatok elvégzésére szükség volt egy Napszimulátorra. Kutatómunkánk előzményeként sikerült kifejlesztenünk egy szabványos Napszimulátort. A napfény-szimulátorokra érvényes követelményekkel az American Standart for Testing and Materials (ASTM) E972-es szabványa foglalkozik. Magyarországon MSZ EN 60904-9:2008 jelöléssel és Fotovillamos eszközök. 9. rész: Napszimulátorok teljesitöképességi követelményei (IEC 60904-9:2007) jelent meg. E szabvány három szempont alapján három különböző osztályba sorolja a szabványos szimulátorokat, azonban a készülékeknek mindhárom kategória esetén biztosítani kell tudni a földfelszíni (AM 1,5), maximálisan $1.000 \mathrm{~W} / \mathrm{m}^{2}$-es átlagos fényintenzitás értéket. Az általunk tervezett és megvalósított napfényszimulátor $\mathrm{C}$ osztályú, tehát mind a térbeli, mind pedig a frekvenciabeli inhomogenitás $10 \%$-nál kisebb értéket képvisel [1, 2, 3, 7].
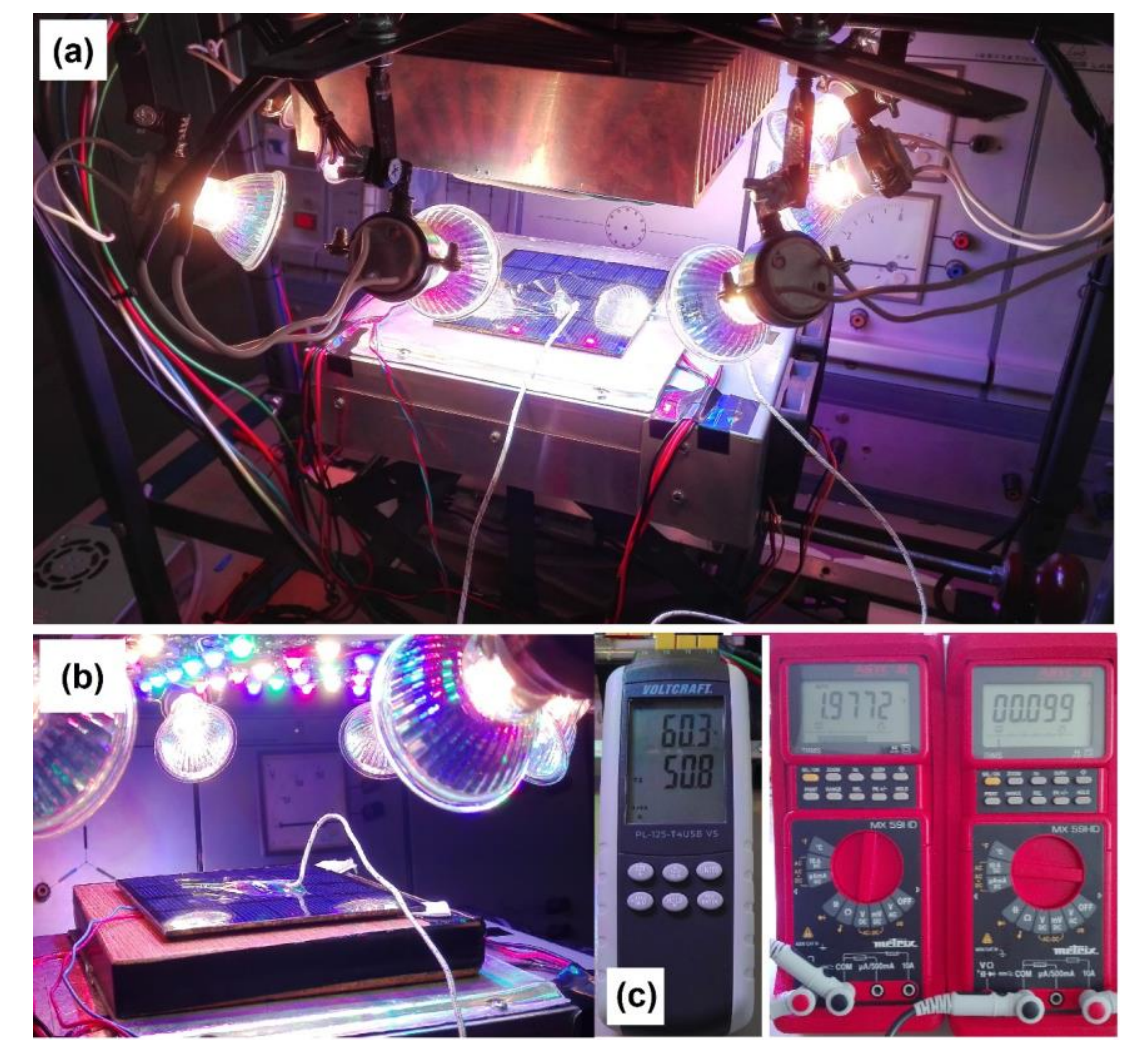

1. ábra. Mérési összeállitás (a), vizsgált napelem (b), hömérséklet-, feszültség- és áramerösség mérés (c). 
A laboratóriumi vizsgálatoknál a hőmérsékleti tranziens során vizsgáltam a terheletlen napelem elektronikai jellemzőinek változását. A napelem cella hőmérsékletének befolyásolását egy Peltier elemek felhasználásával készített hütőmodul biztosítja. A napelem hőmérsékletének mérését egy Voltcraft PL-125-T4 típusú négycsatornás digitális hőmérővel oldom meg, amely másodpercenként méri, illetve menti az eredményeket. Az áramerősség és feszültség méréseket két darab, METEIX MX $59 \mathrm{H}$ típusú digitális multiméter végeztem el. Az 1. ábrán megfigyelhető a kialakított mérő-apparátus.

\section{A mérési eredmények}

A laboratóriumi vizsgálatok két részre bonthatók, egyrészt hőmérsékleti tranziens során vizsgáltam a terheletlen napelem elektronikai jellemzőinek változását, másrészt állandó hőmérséklet és besugárzási értékek mellett vizsgáltam a terhelt napelem karakterisztikáit $[1,5]$.

A mérések minden esetben a korábban ismertetett napszimulátor megvilágítása mellett készültek el, amely szabályozhatósága lehetőséget ad különböző megvilágítási fényintenzitások kialakítására. A mérések során vizsgált polikristályos napelem típusa: XINPUGUANG Mini module, adattábláját az 1. táblázat foglalja össze.

1. táblázat. XINPUGUANG Mini module (napelem cella) adattáblája.

\begin{tabular}{|l|c|c|}
\hline \multicolumn{1}{|c|}{ Megnevezés } & Jele & Értéke \\
\hline Maximális valós teljesítmény & $P_{\max }$ & $0,68 \mathrm{~W}$ \\
\hline Maximális Teljesítményű Pont áramerőssége & $I_{m p p}$ & $0,094 \mathrm{~A}$ \\
\hline Maximális Munka Pont feszültsége & $U_{m p p}$ & $7,2 \mathrm{~V}$ \\
\hline Rövidzárási áramerősség & $I_{r z}$ & $0,115 \mathrm{~A}$ \\
\hline Üresjárási feszültség & $U_{i i j}$ & $8,4 \mathrm{~V}$ \\
\hline Rövidzárási áramerősség hőmérsékleti állandója & $K_{I r z}$ & $0,047 \% /{ }^{\circ} \mathrm{C}$ \\
\hline Üresjárási feszültség hőmérsékleti állandója & $K_{U i i j}$ & $-0,32 \% /{ }^{\circ} \mathrm{C}$ \\
\hline
\end{tabular}

A napelem karakterisztikák meghatározása különböző terhelések esetén mért áramerősség és feszültség értékek alapján történik. A méréseket három fényintenzitás és négy stabilizált hőmérséklet esetére végeztem el. A 3. ábra az áramerősséget mutatja a feszültség függvényében az összes hőmérséklet/fényintenzitás érték esetére. A hőmérséklet értékek esetén eltérések tapasztalhatók adott hütési mód esetére a megvilágítás intenzitásának függvényében. A négy hőmérséklet értéket a következő módokon biztosítjuk: a legmagasabb hőmérséklet elérése érdekében a napelemet egy falap segítségével elszigeteljük a hütőmodultól, hisz az a Peltier-elemek müködése nélkül is hőt von el a hütőborda által; a következő hőmérséklet érték elérésekor a hütőmodulon helyezkedik el a napelem, de az nem müködik; a hütés első fokozata során a hütőmodul maximális teljesítményen müködik; a legalacsonyabb hőmérséklet eléréséhez a hütőmodul hütését a napelem felületének ventilátoros hütésével biztosítjuk. (Jelen mérések elvégzése esetén a léghőmérséklet meghaladja a $32{ }^{\circ} \mathrm{C}$-ot, ez okozza a hütőmodul teljesítményének drasztikus visszaesését.)

Az U-I jelleggörbéit megfigyelve egyértelmü trendeket vehetünk észre. Egyrészt látható, hogy a hőmérséklet csökkenése az üresjárási feszültség növekedését eredményezi, illetve az áramerősség 
kismértékű csökkenése is észrevehető. Látható, hogy amikor előfordul közel azonos hőmérséklet különböző fényintenzitás értékek esetén akkor az üresjárási feszültségek szinte megegyeznek. Ez az üresjárási feszültség hőmérséklet függésének erős- és fényintenzitás függésének gyenge mivoltával magyarázható. Egyértelmű trendként jelenik meg, hogy az üresjárási feszültség nagymértékben függ a fényintenzitástól és ez a függés lineáris, hasonlóan az üresjárási feszültség hőmérsékletfüggéséhez. Hasonló eredményeket láthatunk Skoplaki és szerzőtársainál [5].

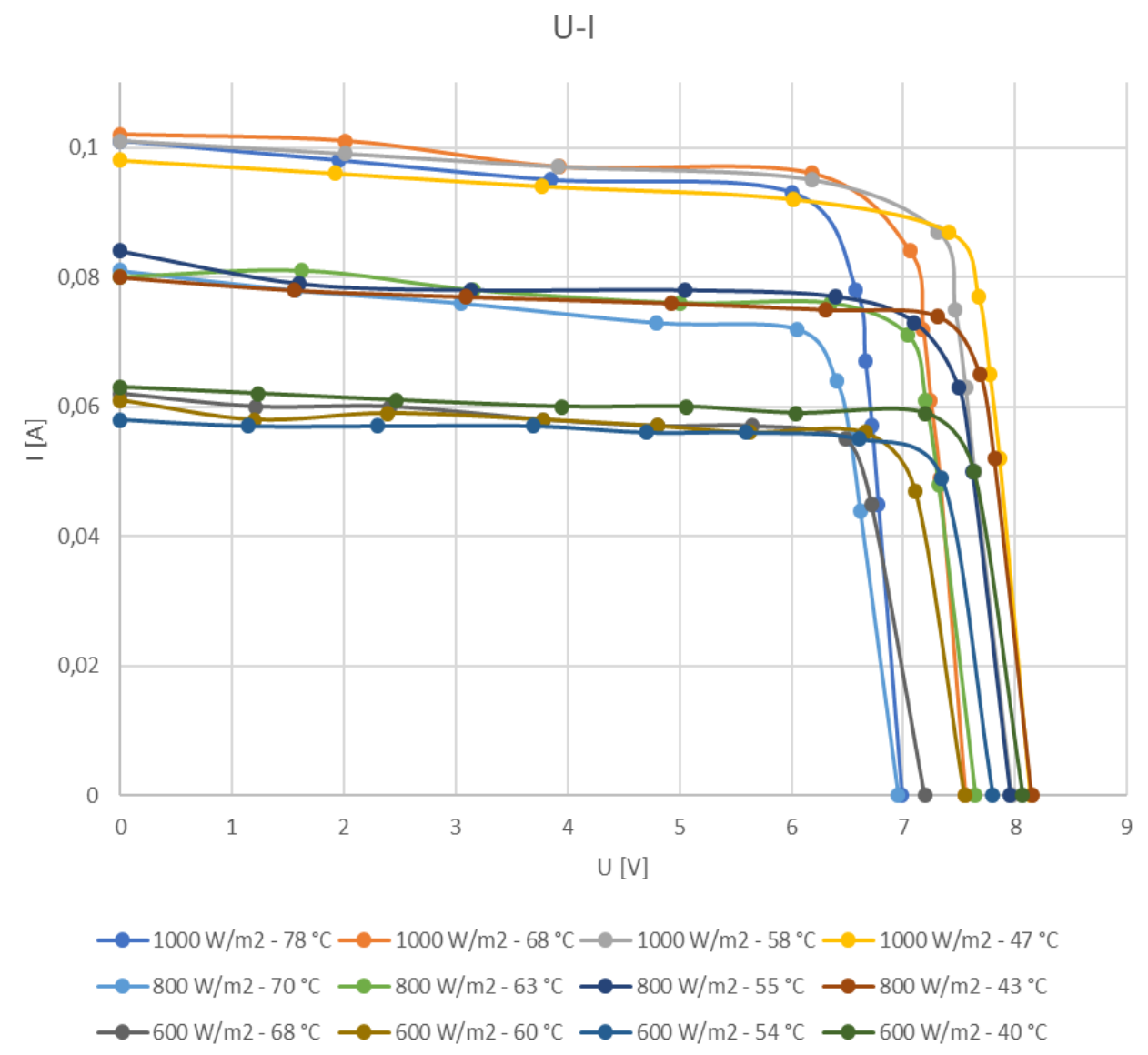

3. ábra. A napelem U-I jelleggörbéi különbözö fényintenzitás- és hömérséklet értékek esetére.

A másik fontos információkat hordozó napelem jelleggörbe a teljesítmény-feszültség grafikon. A teljesítményt a feszültség és az áramerősség szorzataként számíthatjuk. A 4. ábra a teljesítmény alakulását mutatja a feszültség függvényében, -az átláthatóság kedveért- egy fényintenzitás esetén (1.000 $\mathrm{W} / \mathrm{m}^{2}$ ) és a különböző hőmérsékletértékekre. Hasonló eredményeket olvashatunk Munoz-Garcia és szerzőtársai publikációjában [6].

A 5. ábra a teljesítmény alakulását mutatja a feszültség függvényében, $800 \mathrm{~W} / \mathrm{m}^{2}$ fényintenzitás esetén és különböző hőmérsékletértékekre.

A 6. ábra a teljesítmény alakulását mutatja a feszültség függvényében, $600 \mathrm{~W} / \mathrm{m}^{2}$ fényintenzitás esetén és különböző hőmérsékletértékekre. 


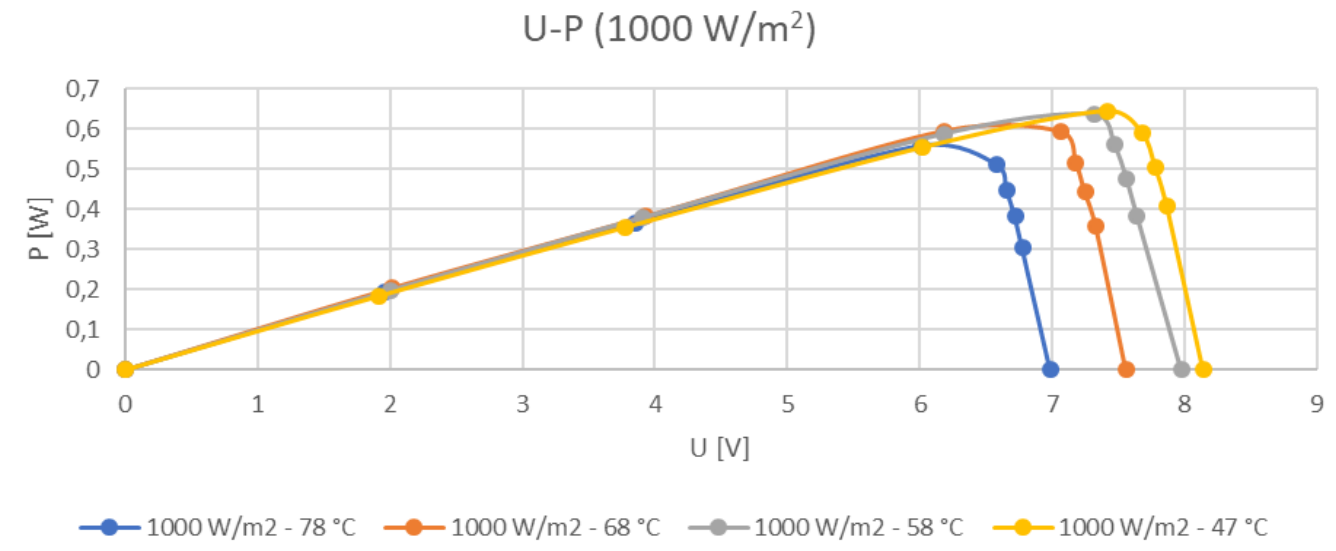

4. ábra. U-P jelleggörbék $1.000 \mathrm{~W} / \mathrm{m}^{2}$ fényintenzitás esetén különbözö hömérsékleteken.

$$
\mathrm{U}-\mathrm{P}\left(800 \mathrm{~W} / \mathrm{m}^{2}\right)
$$

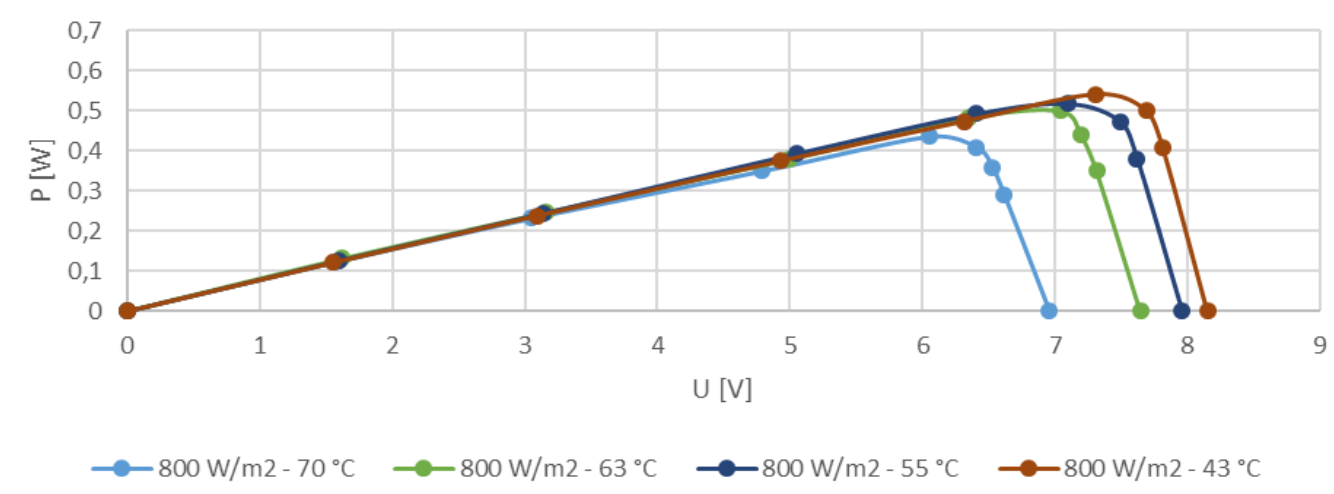

5. ábra. U-P jelleggörbék $800 \mathrm{~W} / \mathrm{m}^{2}$ fényintenzitás esetén különbözö hömérsékleteken.

$$
\mathrm{U}-\mathrm{P} 600 \mathrm{~W} / \mathrm{m}^{2}
$$

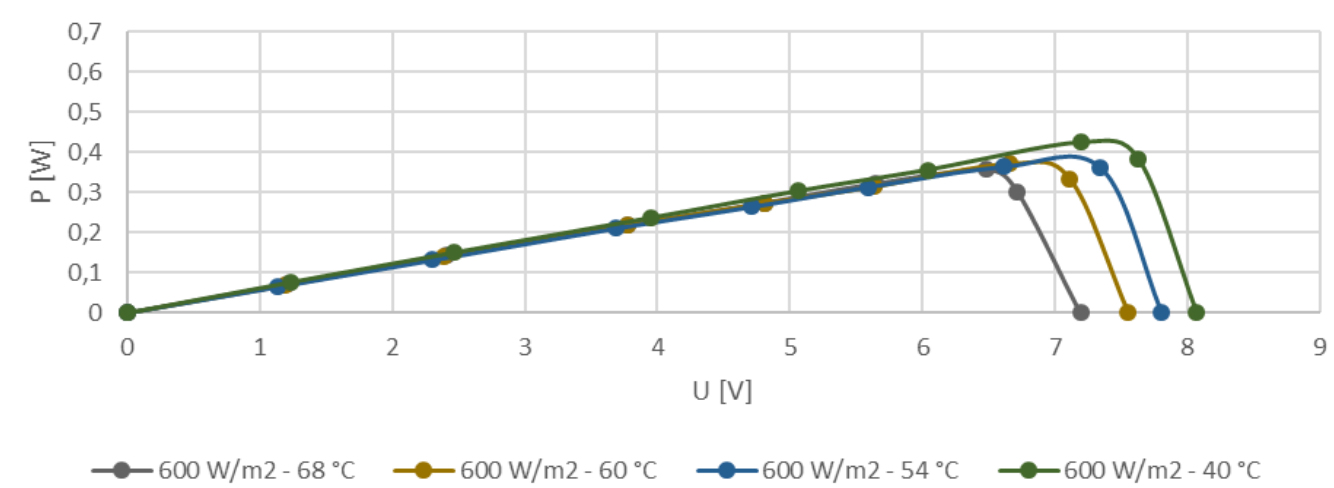

6. ábra. U-P jelleggörbék $600 \mathrm{~W} / \mathrm{m}^{2}$ fényintenzitás esetén különböző hőmérsékleteken. 
A feszültség-teljesítmény ábrákat megfigyelve ugyancsak észrevehető a hőmérséklet és a fényintenzitás maximális teljesítményre gyakorolt hatása. A hőmérséklet növekedésével csökken a napelem maximális teljesítménye (belső ellenállással megegyező terhelés), amelyet a feszültség nagymértékü csökkenése és az áramerősség kismértékü növekedése okoz, amely szorzatuk így csökken. A fényintenzitás csökkenésével -a várható módon- csökken a napelem által maximálisan biztosítható teljesítmény. A leírt hömérséklet és fényintenzitás függések is lineáris viselkedést mutatnak $[4,5,6]$.

Fontos információkat ad a napelem müködési jellemzőiről a teljesítmény ábrázolása a terhelö ellenállás függvényében. A 7. ábra a vizsgált hőmérséklet- és fényintenzitás értékek esetére mutatja az R-P görbéket.

A 7. ábrán megfigyelhető a kapcsolat hőmérséklet és a fényintenzitás változása, illetve a napelem Maximum Teljesítmény Pontjához (MPP) tartozó optimális terhelés értéke között. Látható, hogy a csökkenő fényintenzitás az optimális terhelés értékét növeli. A hőmérséklet növelése pedig az ideális terhelés értékét kismértékben csökkenti. Ez a hatás $600 \mathrm{~W} / \mathrm{m}^{2}$ fényintenzitás esetén már csak elhanyagolható mértékben jelentkezik. Hasonló görbéket találunk Nagy és szerzötársai publikációjában is [4].

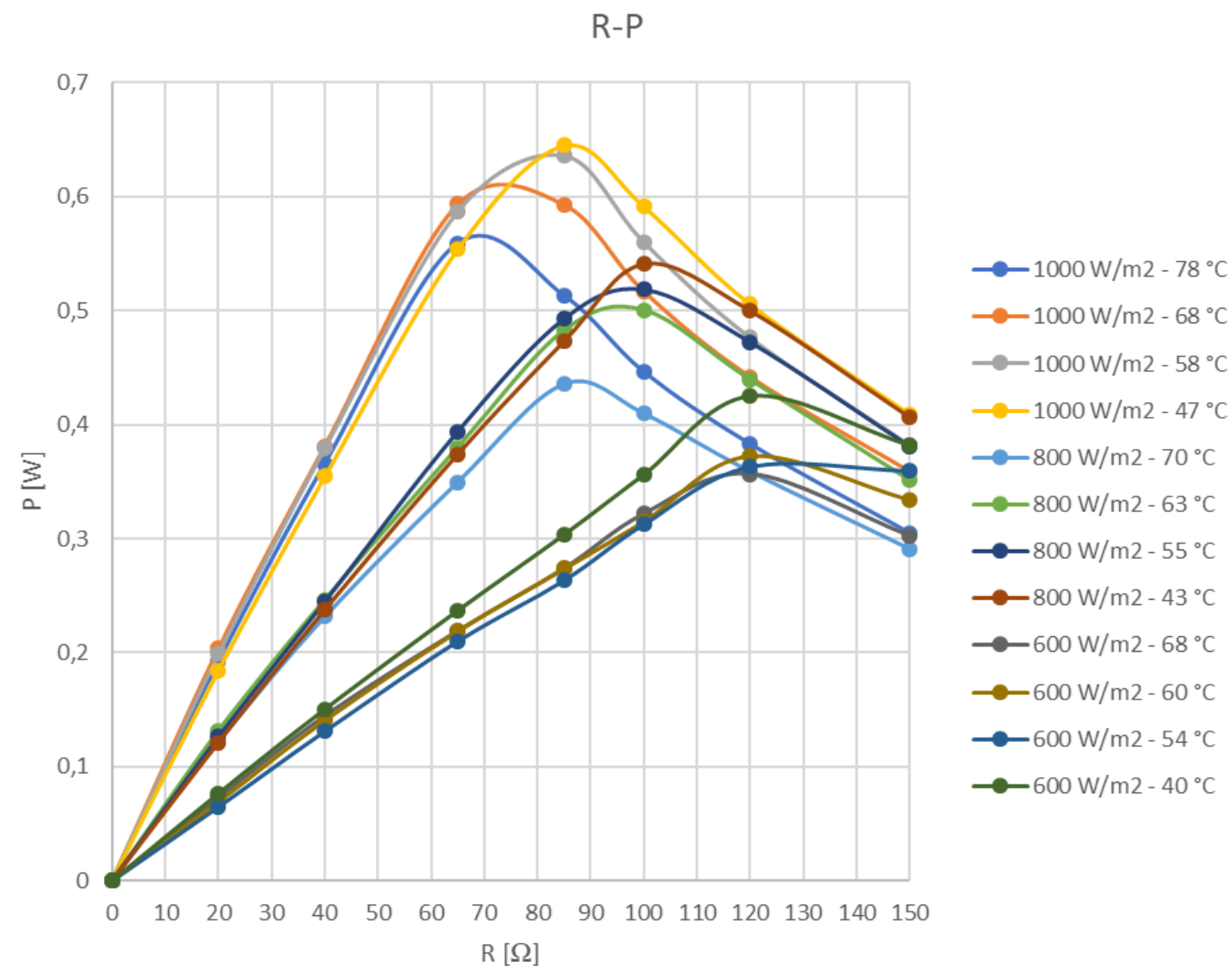

7. ábra. U-P jelleggörbék Terhelö ellenállás - teljesitmény görbék a vizsgált hömérséklet- és fényintenzitás értékek esetén. 


\section{4. Összefoglalás}

Összeségében elmondható tehát, hogy a mérések eredményei visszaigazolták az alapfeltevést, miszerint a hőmérsékletnövekedés a napelem cella hatékonyságát, ez által pedig a teljesítményleadó képességét rontja. A napelemek a valós müködésük során csekély ideig üzemelnek a sztenderd által meghatározott körülmények között, így attól eltérő körülmények között is szükséges a napelemek vizsgálata.

A megvilágítás intenzitásának növelése eredményeként nőtt a napelem által szolgáltatott áramerösség, azonban a hömérséklet is, amely következtében csökkent a feszültsége. A két érték szorzata ugyan nagyobb, mint a kisebb intenzitású megvilágításnál, azonban a hatásfoka csökkent. A 12 mérési görbe alapján elmondható, hogy a napelem hatásfoka a napelem hömérsékletével fordított arányban áll. Minél melegebb a napelem, annál kisebb a hatásfoka. Elektronikai mivoltukból adódóan a tartósan nagy üzemi hőmérséklet az élettartamukat csökkenti. A napelem akkor üzemel a legnagyobb hatásfokkal, ha a benne képződő hő minél nagyobb mértékben elvezetésre kerül, azaz ha hütve van. Természetes hütést biztosít a légáramlás, azaz a szél, vagy a napelemet körülvevő hideg levegő. Tehát télen jobb hatásfokkal üzemelnek a napelemek, mint nyáron.

\section{Köszönetnyilvánítás}

A cikkben ismertetett kutató munka az EFOP-3.6.1-16-2016-00011 jelü „Fiatalodó és Megújuló Egyetem - Innovatív Tudásváros - a Miskolci Egyetem intelligens szakosodást szolgáló intézményi fejlesztése" projekt részeként - a Széchenyi 2020 keretében - az Európai Unió támogatásával, az Európai Szociális Alap társfinanszírozásával valósul meg.

\section{Irodalom}

[1] Bodnár, I.: Electric parameters determination of solar panel by numeric simulations and laboratory measurements during temperature transient. Acta Polytechnica Hungarica. 2018, 15(4):5982. https://doi.org/10.12700/APH.15.4.2018.4.4

[2] Faragó, D., Bodnár, I., Bencs, P., Koós, D., Iski, P., Skribanek, Á.: Laboratory measurements and numeric simulation of a solar cell. 2019 20th International Carpathian Control Conference (ICCC). Article number 105. https://doi.org/10.1109/CarpathianCC.2019.8765927

[3] Malik, A.Q., Damit, S.J.B.H.: Outdoor testing of single crystal silicon solar cells. Renewable Energy 2003, 28:1433-1445. https://doi.org/10.1016/S0960-1481(02)00255-0

[4] Nagy, D., Rácz, E., Varga, A. Ruf, H., Neuchel, E., R.: Comparison of electric current - voltage, characteristics and maximal power point values of differently and artificially aged solar panels. Proceedings of the $13^{\text {th }}$ IEEE International Symposium on Applied Computational Intelligence and Informatics. 2016. pp. 295-300. https://doi.org/10.1109/SACI.2016.7507389

[5] Skoplaki, E., Palyvos, J.A.: On the temperature dependence of photovoltaic module electrical performance: A review of efficiency/power correlations. Solar Energy 2009, 83(5):614-624. https://doi.org/10.1016/j.solener.2008.10.008

[6] Munoz-Garcia, M.A., Marin, O., Alonso-García, M.C., Chenlo, F.: Characterization of thin film PV modules under standard test conditions: Results of indoor and outdoor measuremnets and the effects of sunlinght exposure. Solar Energy 2012, 86(10):3049-3056. https://doi.org/10.1016/j.solener.2012.07.015 
[7] Yadav, P., Pandey, K., Bhatt, V., Kumar, M., Kim, J.: Critical aspects of impedance spectroscopy in silicon solar cell characterization: A review. Renewable and Sustainable Energy Reviews 2017, 76:1562-1578. https://doi.org/10.1016/j.rser.2016.11.205 